\title{
REKOMENDASI MODEL BISNIS BARU WIFI BERBASIS TEKNOLOGI WIFI ON CLOUD MANAGEMENT BAGI KEUNGGULAN BERSAING PROVIDER WIFI DI INDONESIA
}

\author{
Ratih Ruffianti \\ Researcher Business, Divisi Digital Service \\ PT Telekomunikasi Indonesia Tbk \\ Arif Effendi \\ Researcher Billing Management, Divisi Digital Service \\ PT Telekomunikasi Indonesia Tbk \\ Anis Sirwan \\ Researcher Payment, Divisi Digital Service \\ PT Telekomunikasi Indonesia Tbk
}

\begin{abstract}
Teknologi WoCM atau Wifi on Cloud Management merupakan teknologi cloud yang dimanfaatkan dalam konfigurasi wifi. Teknologi ini dimiliki oleh penyedia teknologi seperti Mojo Networks, Cloud4Wi, dan Tanaza. Provider wifi dunia seperti British Telecom dan Singtel telah menerapkan teknologi ini untuk meningkatkan value dari bisnis wifi bagi pelanggannya dari segmen enterprise. Provider wifi di Indonesia perlu menerapkan teknologi WoCM agar bisa memiliki keunggulan bersaing lewat elaborasi layanan eksisting connectivity ke tingkat yang lebih advance. Benefit dari Wifi on Cloud Management terletak pada fitur-fitur utama yaitu data analytics yang mengubah data menjadi insight, targetted advertising, captive portal yang dapat dikastemisasi, survey on line untuk mengetahui reaksi end user terhadap program promosi secara real time, dan dashboard performansi yang memberikan kontrol penuh bagi segmen enterprise dalam memonitor performansi bisnis. Keseluruhan fitur-fitur tersebut dapat meningkatkan engagement antara segmen enterprise dengan end user atau pelanggannya. Pada akhir tulisan, dipaparkan rekomendasi model bisnis baru bagi penyedia wifi di Indonesia dan rekomendasi lainnya dalam mengimplementasikan layanan wifi berbasis teknologi WoCM.
\end{abstract}

Keywords:

wifi, Wifi on Cloud Management, WoCM, cloud, connectivity, VAS, model bisnis, advance 


\section{PENDAHULUAN}

Selama bertahun-tahun sampai saat ini, provider wifi di Indonesia masih menawarkan layanan connectivity. Belum ada penyedia wifi di Indonesia yang memiliki layanan dengan benefit yang lebih advance dibanding layanan dasar connectivity. Model bisnis penyedia wifi masih terbatas pada penawaran paket kecepatan dan harga. Sementara itu operator telco atau provider wifi dunia telah menawarkan layanan wifi diluar paket kecepatan dan harga kepada segmen enterprise.

Layanan wifi tersebut memiliki fiturfitur utama yang sangat bermanfaat bagi segmen enterprise dalam usahanya untuk meningkatkan performansi bisnis. Sangat penting bagi provider wifi di Indonesia untuk mengetahui dan memahami teknologi yang mendasari layanan wifi yang dimiliki provider wifi dunia tersebut. Teknologi yang dimaksud adalah teknologi WoCM (Wifi on

\section{Cloud Management).}

Tim Researcher Telkom Divisi

Digital Service telah mengkaji teknologi tersebut dan merumuskan rekomendasi model bisnis baru dan rekomendasi lainnya bagi provider wifi di Indonesia. Penjelasan konsep teknologi, hasil benchmark terhadap penyedia teknologi WoCM dan provider wifi dunia, serta rekomendasi bagi provider wifi di Indonesia akan dipaparkan dalam tulisan ini. Harapannya, tulisan ini menjadi masukan atau insight yang bermanfaat bagi para provider wifi di Indonesia untuk mengembangkan layanan wifi ke tingkat yang lebih advance. Dengan memiliki diferensiasi layanan, penyedia wifi yang mengimplementasikan teknologi ini akan dapat mengungguli pesaingnya. 


\section{TINJAUAN TEORI DAN PENGEMBANGAN HIPOTESIS}

Terdapat berbagai istilah untuk teknologi cloud yang dimanfaatkan dalam wifi, seperti Cloud Managed Wifi dan Cloud Controller Wifi. Secara umum istilahistilah tersebut memiliki pengertian yang sama. Untuk lebih memudahkan pengertian terhadap konsep teknologi tersebut, Tim Researcher Telkom Divisi Digital Service menggunakan istilah Wifi on Cloud Management (WoCM) dan mengacu pada konsep cloud Microsoft. Selain itu teori yang dijadikan acuan adalah teori business model generation. Tulisan ini akan menjawab hipotesa bagaimana dengan penerapan konsep teknologi WoCM suatu provider wifi akan memperoleh solusi untuk dapat meningkatkan layanan wifi eksisting menjadi layanan wifi yang memiliki diferensiasi dibanding layanan wifi yang ditawarkan oleh provider wifi lainnya.

\subsection{Metode Penelitian}

Penelitian ini memakai metode desk research yang dilaksanakan antara bulan Januari 2016 sampai April 2016.

\subsection{Konsep Teknologi Wifi on Cloud Management}

Konsep teknologi Wifi on Cloud Management (WoCM) sangat terkait erat dengan teknologi cloud. Teknologi cloud sendiri dibagi kedalam beberapa model yaitu:

a. Private Cloud: infrastruktur layanan cloud dioperasikan hanya untuk sebuah organisasi atau perusahaan tertentu yang biasanya memiliki skala besar.

b.Community Cloud: infrastruktur layanan cloud digunakan bersama-sama oleh beberapa organisasi atau perusahaan yang memiliki kesamaan kepentingan.

c. Public Cloud: layanan yang disediakan penyedia layanan cliud untuk umum atau group perusahaan. 
d.Hybrid Cloud: komposisi dari dua atau lebih infrastruktur cloud (private, community, atau public). Meskipun secara entitas berdiri sendiri-sendiri., tapi dihubungkan oleh suatu teknologi/ atau mekanisme yang memungkinkan portabilitas data dan aplikasi antar cloud tersebut. Misalnya, mekanisme load balancing yang dilakukan antar cloud, sehingga alokasi sumber daya bisa dipertahankan pada level yang optimal.

Suatu perusahaan yang memanfaatkan cloud akan memperoleh keuntungan antara lain :

a. Tidak perlu mengeluarkan investasi awal yang signifikan karena investasi dilakukan oleh penyedia layanan cloud sedangkan perusahaan hanya menyewa. Disini kapasitas dapat disesuaikan sesuai kebutuhan.

b.Pengeluaran untuk capex seperti investasi hardware dan software dapat diubah menjadi pengeluaran operasional atau opex yang akan dikeluarkan secara bulanan sesuai dengan pemakaian layanan yang dibutuhkan.

c.Dengan cloud akan mengakomodasi kebutuhan penambahan kapasitas yang sifatnya temporer atau sewaktu-waktu, dimana bila dibandingkan tanpa cloud, fasilitas ini harus didesain dari awal untuk mengantisipasi kebutuhan yang tinggi yang tentunya dapat meningkatkan biaya start up. Jadi dengan pemakaian cloud diperoleh fleksibilitas dan kemudahan.

d.Dengan pemakaian cloud yang disediakan oleh penyedia layanan cloud maka perusahaan atau dapat memfokuskan diri pada pengelolaan dan pengembangan service dan bisnisnya, tidak lagi fokus dalam pengelolaan hardware dan software infrastruktur. Pengelolaan hardware, dll, telah dilakukan oleh penyedia layanan cloud. Apabila perusahaan memiliki tim IT sendiri, maka tim tersebut dapat lebih 
fokus pada layanan IT yang spesifik untuk keperluan bisnis.
Gambar 1. berikut menyajikan berbagai tingkatan layanan dalam cloud.
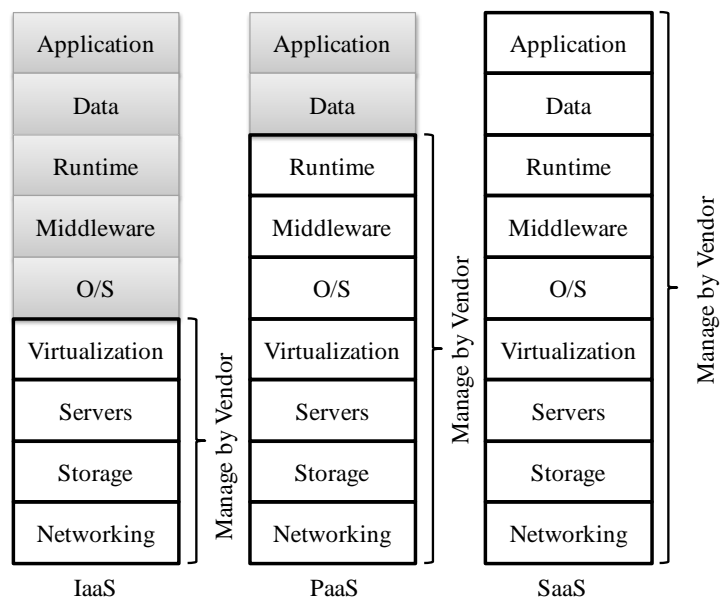

Gambar 1.

Tingkatan Layanan Cloud

Gambar 1. tersebut memperlihatkan bahwa penyedia layanan cloud menawarkan layanan cloud bisa sebagai IaaS (Infrastructure as a Service), Paas (Platform as a Service), atau Saas (Software as a Service). Layanan cloud ditawarkan sebagai SaaS apabila seluruh cloud network element dikelola oleh penyedia layanan cloud mulai dari application sampai networking. Inilah yang disebut sebagai konsep teknologi Cloud Management.
Adapun arsitektur dari teknologi WoCM sebagai berikut. 


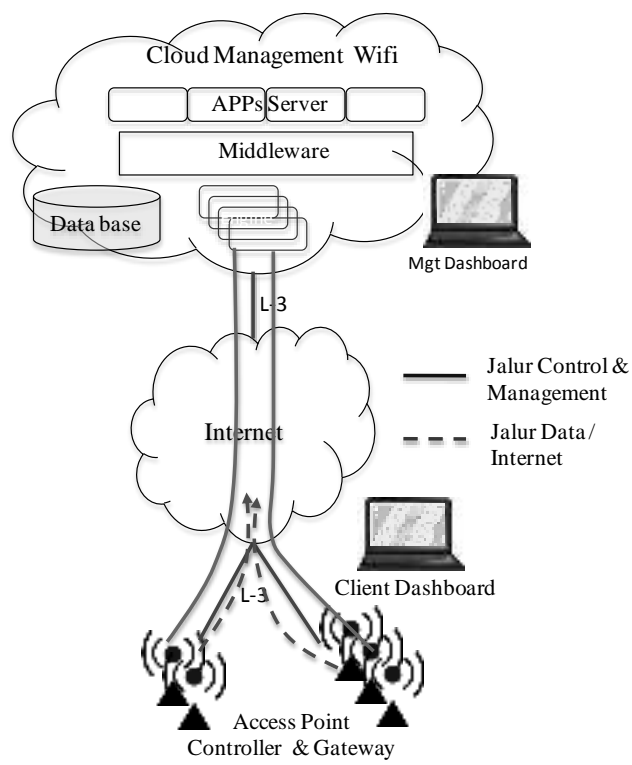

Gambar 2.

Arsitektur Teknologi WoCM

Berdasarkan Gambar 2. diatas, dapat

dilihat bahwa perangkat access point memiliki fungsi radio, controller, dan gateway. Sedangkan fungsi manajemen dilakukan pada cloud engine. Untuk updating fungsi radio, routing dilakukan dari cloud ke access point dan ini dilakukan hanya bila terjadi perubahan konfigurasi.

\section{Koneksi antar access point} dilakukan melalui layer-3 koneksi. Didalam koneksi ini hanya terdapat fungsi jalur manajemen access point sedangkan jalur data dilakukan pada access point. Dengan demikian layanan yang sedang berjalan tidak akan terganggu walaupun jalur menuju Cloud terputus. Arsitektur diatas lebih fleksibel sifatnya dimana kapasitasnya tergantung pada kapasitas dan kapabilitas engine cloud sehingga akan lebih optimal. Arsitektur semacam itu disebut juga dengan Software as a Service. 


\subsection{Konsep Model Bisnis}

$$
\text { Sebuah model bisnis }
$$

menggambarkan dasar pemikiran tentang bagaimana organisasi menciptakan, memberikan, dan menangkap nilai . Model bisnis dijelaskan melalui 9 blok bangunan dasar yang terbagi ke dalam 4 bagian utama yaitu pelanggan, penawaran, infrastruktur dan finansial. Apabila digambarkan dalam suatu kanvas, model bisnis tergambar seperti Gambar 3. berikut :

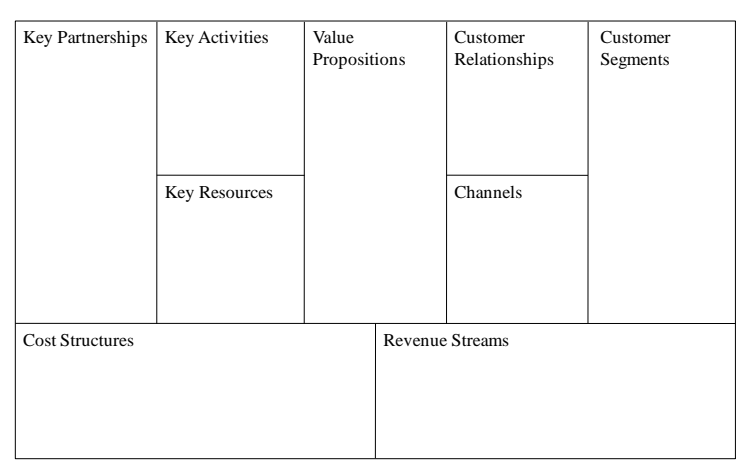

Gambar 3.

Sembilan Blok dalam Model Bisnis

Berikut penjelasan masing-masing

bagiannya :

a.Customer segments: suatu organisasi melayani satu atau beberapa segmen pelanggan.

b. Value propositions: memecahkan masalahmasalah pelanggan dan memuaskan kebutuhan pelanggan melalui proposisi nilai. c. Channels: proposisi nilai akan sampai ke pelanggan melalui komunikasi, distribusi, dan saluran penjualan.

d.Customer relationships: pengelolaan hubungan ke pelanggan.

e.Revenue streams: pendapatan yang dihasilkan dari proposisi nilai yang ditawarkan ke pelanggan. 
f. Key resources: aset yang diperlukan untuk dapat memberikan proposisi nilai ke pelanggan.

g. Key activities : aktivitas-aktivitas utama untuk memberikan proposisi nilai ke pelanggan.

h.Key partnerships: kerjasama yang dilakukan sebuah organisasi baik dari segi aktivitas maupun aset atau sumber daya. i. Cost structure: elemen-elemen model bisnis berpengaruh pada struktur biaya.

\subsection{Penyedia Teknologi WoCM}

Berdasarkan hasil desk research dapat dikenali beberapa penyedia teknologi WoCM antara lain Cloud4Wi, Tanaza, Mojo Networks, dan Cisco Meraki.

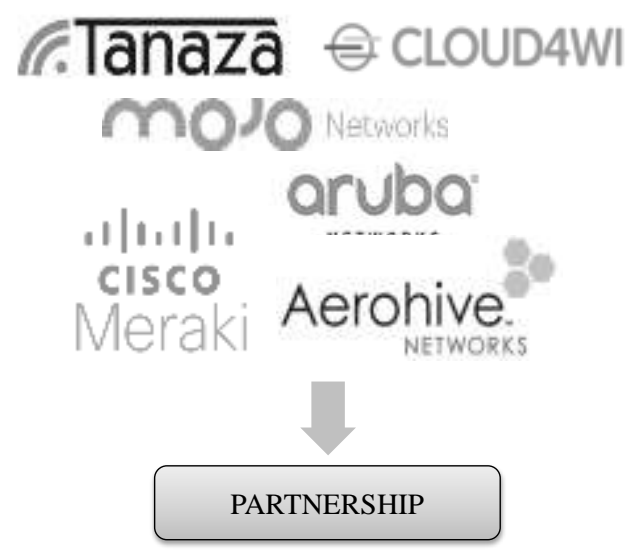

Gambar 4.

Penyedia Teknologi Wifi on Cloud Management

Penyedia teknologi WoCM tersebut

(Gambar 4.) saling bekerjasama satu dengan yang lain seperti yang dilakukan antara Cisco Meraki dan Cloud4Wi, Cloud4Wi dan
Tanaza, Cloud4Wi dan Aerohive, Cloud4Wi dan Cisco, dst.

Secara garis besar layanan wifi yang ditawarkan oleh penyedia teknologi WoCM memiliki fitur-fitur yang serupa, meliputi 
analytics, advertising, portal, survey on line, dan dashboard. Berikut contoh dari fitur- fitur penyedia teknologi WoCM Cloud4Wi

(Gambar 5.).

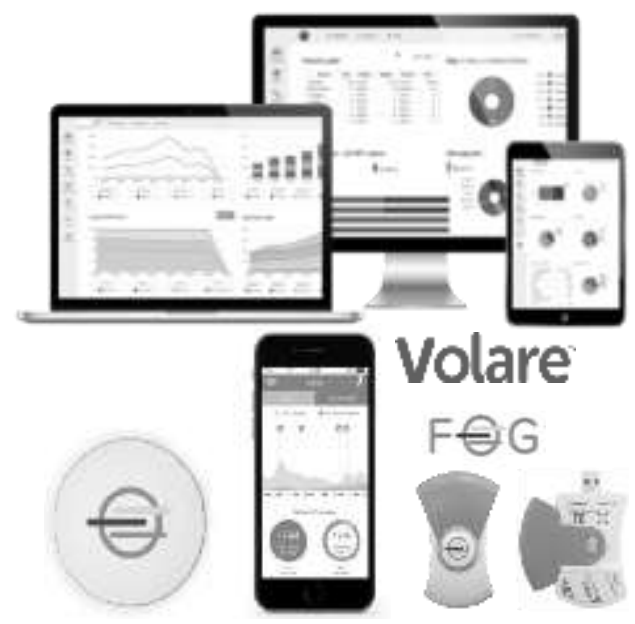

Gambar 5.

Produk Cloud4Wi

Cloud4Wi memilki 3 produk utama yaitu Volare, Fogsense, dan Fogspot.

a. Volare. Volare disebut sebagai open $\mathrm{WiFi}$ engagement platform (Guest Wifi management platform). Manfaat yang ditawarkan bagi enterprise adalah sebagai media untuk meningkatkan engagement, loyalitas, dan retention, lewat aplikasi analytics, push marketing, dan advertising. Volare memiliki 3 jenis paket bundling yaitu paket standard, professional, dan enterprise edition. Perbedaannya terletak pada jenis data analytics dan API. Saat ini Cloud4Wi sudah meliris Volare 6.0.

b.Fogsense. Semacam dongle dengan tambahan plug and play sensor. Fogsense mudah diinstal dan bisa diletakkan dimana saja (meja, dinding, dll). Manfaat yang ditawarkan antara lain kemampuan mengukur jumlah end user, aktivitas, durasi, termasuk menemukenali area di lokasi bisnis enterprise yang sering 
diduduki end user. Dengan adanya Fogsense, enterprise dapat menawarkan konten-konten promosi yang relevan. Fogsense ini ditawarkan sebagai adds on dari Volare.

c. Fogspot. Layanan ini baru tersedia di US dan Canada. Manfaat yang ditawarkan adalah enterprise dapat memonitor end user lewat mobile apps. Sebagai contoh, end user dari suatu cafe akan melakukan login lewat social media terlebih dahulu. Setelah berhasil login kepada end user akan disajikan welcome page dimana didalamnya terdapat spesial promo dan kupon. Bahkan setelah end user meninggalkan cafe tersebut, kepada end user akan dikirimkan email marketing. Keseluruhan proses ini bisa dimonitor cafe yang bersangkutan lewat mobile apps. Adapun platform Fogspot meliputi guest wi-fi welcome page, dashboard analytics, applications, platform management (mobile apps dan web), guest wi-fi login options, serta customer management (trouble shooting, profiling). Industri yang dilayani CLoud4wi meliputi industri hotel, retails, shopping mall, restaurant, dll. Demikian pula halnya dengan industri yang dilayani oleh penyedia teknologi WoCM lainnya. Hal penting lainnya adalah Cloud4Wi dapat terkoneksi dengan berbagai equipment vendors yang berbeda-beda (vendor agnostic). 


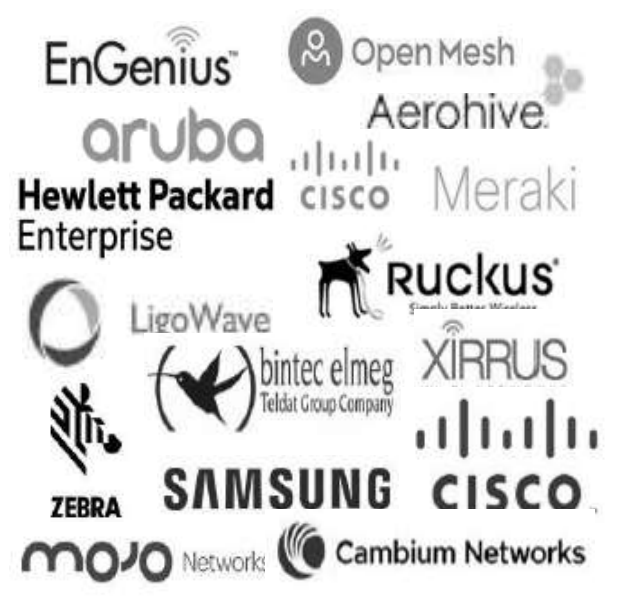

Gambar 6.

Partner Access Point \& Controller Cloud4Wi

Selain kerjasama dengan partner

perangkat (Gambar 6.), penyedia teknologi

WoCM juga menjalin kerjasama dengan

mitra lainnya dengan tujuan untuk

memperluas layanan atau services.

Contohnya kerjasama yang dilakukan oleh
Tanaza yang menjalin kerjasama dengan mitra spesialis inbound marketing software platform, customer service software, email marketing services, CRM software, marketing automation software, dan spesialis online marketing (Gambar 7.).

\section{Hubspót "źt zendesk

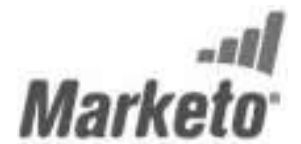 \\ salesforce

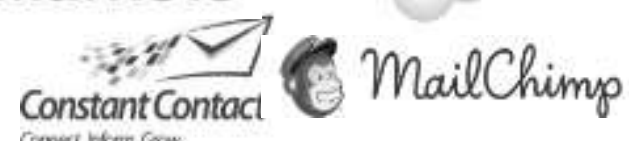 \\ comer. hom crose}

Gambar 7.

Partner Layanan Tanaza 
IDC Insight Report menyebutkan

potensi revenue dari cloud-managed

infrastructure dan managed service akan

mencapai \$2.5 billion pada tahun 2018. Hal

ini dikontribusi oleh meningkatnya adopsi

cloud managed wifi baik di perusahaan besar

maupun menengah. Hal ini mengindikasikan

bahwa pemakaian teknologi WoCM akan

semakin diminati segmen enterprise.
Berdasarkan paparan Tanaza dan

hasil analisa dapat diidentifikasi bahwa

enterprise saat ini menghadapi tantangan

bisnis (Gambar 8.) yang harus dihadapi yaitu

peningkatan user experience dan

kemampuan untuk menarik calon pelanggan,

melakukan engagement, dan mengubahnya

menjadi pelanggan. Teknologi WoCM

menjadi solusi bagi enterprise dalam

menjawab tantangan tersebut .

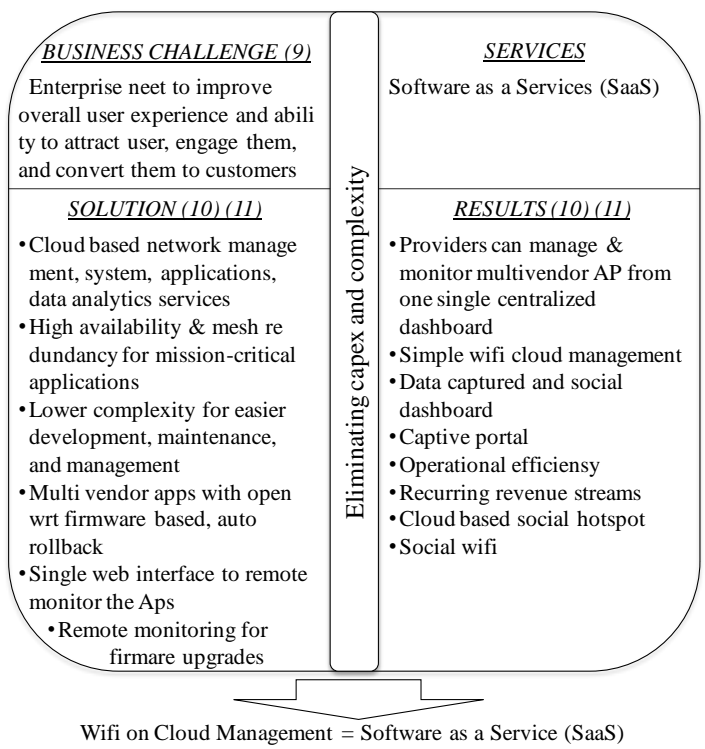

Gambar 8.

Tantangan Bisnis Enterprise dan Solusi Teknologi WoCM 
2.5 Penyedia Wifi di Indonesia

Telkom, Indosat, Biznet, dll eksisting di Indonesia. Layanan wifi yang ditawarkan baru sebatas pada paket

(Gambar 9.), merupakan penyedia wifi kecepatan dan harga.

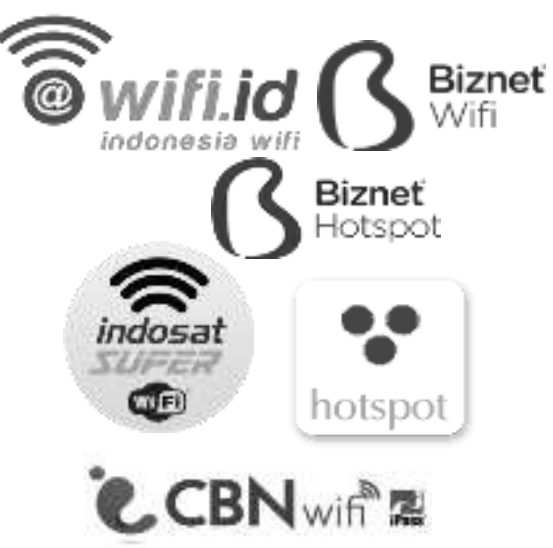

Gambar 9.

Penyedia Wifi Eksisting di Indonesia

Tabel 1. berikut menyajikan yang ditawarkan masih berkisar pada fungsi

beberapa paket produk dari provider wifi di wifi sebagai connectivity.

Indonesia. Dapat dilihat bahwa layanan wifi

Tabel 1.

Produk Wifi di Indonesia

\begin{tabular}{||l||l||l||}
\hline \multicolumn{1}{|c|}{ Provider } & \multicolumn{1}{|c|}{ Produk } & \multicolumn{1}{|c|}{ Keterangan } \\
\hline \hline Telkom & Wifi ID, Wifi Corner & $\begin{array}{l}\text { Wifi Corner : kecepatan up to 100 Mbps, di lebih } \\
6.000 \text { lokasi, voucher elektrik, potong pulsa. }\end{array}$ \\
\hline \hline Biznet (12) & Biznet Wifi & $\begin{array}{l}\text { Kategori home, kecepatan up to 100Mbps, voucher, } \\
\text { login di 2 device. }\end{array}$ \\
\hline \hline Biznet (13) & Biznet Hotspot & $\begin{array}{l}\text { Free wifi dari produk solusi Biznet, di lokasi 7- } \\
\text { eleven, apartment, institusi pendidikan, foodcourt, dll, } \\
\text { up to 2 Mbps. }\end{array}$ \\
\hline CBN (14) & CBN Wifi & Kategori broadband, kecepatan up to 5 Mbps. \\
\hline \hline Melsa (15) & Hotspot Free, Hotspot Matic, & $\begin{array}{l}\text { Hotspot Free untuk 15-30 menit, Hotspot Matic 384 } \\
\text { Kbps untuk 4 jam, Hotspot Premium 1024 Kbps } \\
\text { untuk waktu yang tidak ditentukan. }\end{array}$ \\
\hline \hline Indosat (16) & Indosat Ooredoo Super Wifi & $\begin{array}{l}\text { Kategori produk personal/paket internet, aktivasi ke } \\
\text { SMS no tertentu. }\end{array}$ \\
\hline
\end{tabular}


Segmen pasar yang dilayani terdiri dari segmen retail dan segmen enterprise. Biasanya provider wifi seperti Telkom menyediakan layanan free wifi di lokasilokasi public. Ataupun layanan wifi berbayar dengan menggunakan voucher atau SMS ke nomor tertentu. Sedangkan untuk melayani segmen enterprise, wifi diberikan sebagai fitur dari paket solusi yang dibutuhkan oleh segmen enterprise, dimana kemudian segmen enterprise ini akan me-retailkan kembali wifi tersebut secara free ke end user (Gambar 10.).

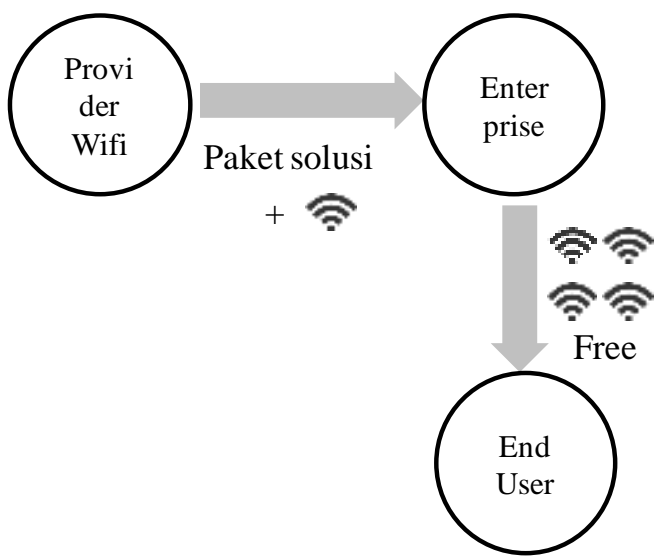

Gambar 10.

Wifi sebagai Fitur pada Paket Solusi Segmen Enterprise

Kondisi ini telah berlangsung

bertahun-tahun lamanya :

a.Penyedia wifi hanya memberikan fitur wifi connectivity untuk setiap paket solusi yang dibutuhkan segmen enterprise, dan

b.Segmen enterprise memberikan free connecitivity kepada end user.
Belum ada benefit lain yang bisa diberikan baik oleh provider wifi maupun segmen enterprise selain connectivity.

\subsection{Benchmark}

British Telecom dan Singtel (Gambar 11.) merupakan provider wifi dunia yang telah mengimplementasikan teknologi 
WoCM dalam men-delivery layanan wifi kepada segmen enterprise.

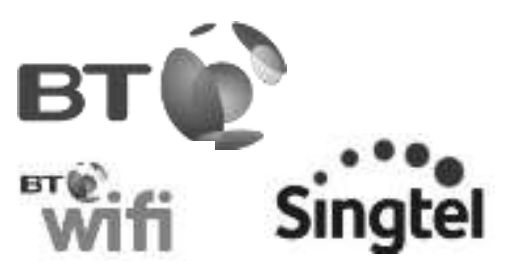

\section{Enterprise WiFi-as-a-Service}

WiFi-as-a-service Analytics

Gambar 11.

BT Wi-fi dan Singtel WiFi

Key features yang ditawarkan BT

Wi-fi terutama dashboard dan intelligent

analytics . Sesuai keterangan dalam Tabel 2.

berikut, dashboard dapat dikastemisasi

sesuai dengan kebutuhan enterprise

termasuk menggabungkan data yang ada ke dalam berbagai tools bisnis lain misalnya CRM tool. Selanjutnya data tersebut masuk ke proses data analytics dengan output berupa insight bisnis untuk segmen enterprise.

Tabel 2.

Fitur Dashboard \& Analytics BT Wi-fi

\section{Customisable Dashboard}

- $\quad$ Tailor the dashboard the way you want it

- Modify the metrics for different roles and levels within organization, from COO to store manager

- Import data to understand sales conversion rates

- Export data into your CRM tool

\section{Intelligent Analytics}

- Data is gathered from all wifi enabled service inside and nearby your venue

- World-class data analytics translate this information into insight

- Rules separate out staff device from customer's device

- $\quad$ The outside opportunity is assessed from people just walking by

Singtel mengkategorikan layanan

wifi untuk enterprise ke dalam kategori

Managed Enterprise WiFi yang terdiri dari layanan Enterprise WiFi-as-a-Service dan

WiFi-as-a-service Analytics dengan benefit 
dan key features seperti pada Tabel $3 . \quad$ berikut.

Tabel 3.

Singtel Wifi untuk Segmen Bisnis

\begin{tabular}{|c|c|c|}
\hline & Enterprise Wifi as a Service & Wifi as a service Analytics \\
\hline Benefits & \multicolumn{2}{|c|}{$\begin{array}{l}\text { - Pas-as-you-grow model } \\
\text { - A central online portal to manage Wifi network, generate user } \\
\text { response, track performance, monitor capacity } \\
\text { - Using data analytic will unlock valuable information and drive } \\
\text { marketing initiatives } \\
\text { - ICT support, maintenance } 24 / 7\end{array}$} \\
\hline Key Features & $\begin{array}{l}\text { - Enterprise-grade, high speed } \\
\text { Wifi access } \\
\text { - Captive login portal with } \\
\text { advertisements (customized } \\
\text { login portal) } \\
\text { - Questionnaires } \\
\text { - Social media capabilities }\end{array}$ & $\begin{array}{l}\text { - Vendor agnostic support } \\
\text { - Intelligence } \\
\text { - Self-service } \\
\text { - Extandable (Application } \\
\text { Integration and API) } \\
\text { - Enhanced, innovative and } \\
\text { targeted digital marketing } \\
\text { capabilities (big data to smart } \\
\text { data, branding, login with ads, } \\
\text { socmed capabilities, } \\
\text { dashboard with built-in data } \\
\text { analytics \& marketing tools) }\end{array}$ \\
\hline
\end{tabular}

Layanan Enterprise WiFi-as-a-

Service menyediakan one-stop managed services termasuk WLAN, network implementor, H/W, S/W, serta Operation \& Maintenance (OM). Wifi network Singtel dapat mengidentifikasi perilaku dari pengguna dan mengolah serta menyajikan insight tentang pengguna. Layanan Wifi-asa-Service Analytics menawarkan pengolahan data analytic terhadap big data yang dimiliki segmen enterprise menjadi smart data, menyajikan hasilnya berupa business insight bagi segmen enterprise, sehingga segmen enterprise akan menyusun berbagai program yang tentunya akan lebih tepat dalam meningkatkan customer engagement dan customer experience. 
III. KESIMPULAN

\section{REKOMENDASI}

\subsection{Kesimpulan}

Berdasarkan pemaparan diatas dapat disimpulkan bahwa teknologi WoCM dapat menjadi solusi bagi penyedia wifi eksisting di Indonesia untuk memiliki layanan wifi yang memiliki fitur-fitur yang lebih advance atau disebut juga dengan istilah VAS Advance WoCM. Dengan diferensiasi layanan tersebut, suatu provider wifi akan lebih unggul dibandingkan pesaingnya. UVP atau unique value propositions yang akan ditawarkan kepada segmen enterprise adalah sebagai tools yang bermanfaat untuk meningkatkan engagement antara segmen enterprise dengan end user dan untuk meningkatkan performansi bisnis segmen enterprise.

\subsection{Rekomendasi bagi Penyedia Wifi di Indonesia}

Berdasarkan manfaat dari teknologi WoCM serta hasil benchmark ke provider wifi dunia, berikut rekomendasi yang bisa diimplementasikan oleh penyedia wifi di Indonesia untuk pengembangan bisnis wifi yang dimiliki:

a. Provider wifi perlu mengembangkan model bisnis baru layanan wifi:

- Value Propositions

Segmen enterprise akan memperoleh manfaat berupa peningkatan engagement dengan pelanggan, peningkatan kepuasan dan loyalitas pelanggan, serta peningkatan revenue dan performansi bisnis lainnya, yang diperoleh melalui fitur-fitur utama data analytics (dengan dukungan big data), advertising produk yang dapat menyasar target pelanggan secara tepat, penyelenggaraan survey online secara real time, serta pengelolaan dashboard 
performansi yang dapat dikontrol penuh oleh segmen enterprise.

- Customer Segments

- Segmen enterprise yang meliputi perusahaan besar, menengah, dan kecil.

- Segmen enterprise pada industri F\&B, education, FMCG, healthcare, hospitality, shopping mall, transportation, financial services, government, dll.

- Channels

- Komunikasi melalui website dan social media (facebook, twitter, line) yang dimiliki provider wifi.

- Sosialiasi melalui acara gathering bagi segmen enterprise.

- Account manager

- Revenue Streams

- Revenue diperoleh melalui connectivity eksisting.

- Tambahan revenue diperoleh melalui VAS Advance WoCM.
- Revenue diperoleh melalui bundling connectivity wifi dengan VAS Advance WoCM.

- Revenue diperoleh dengan skema pay as you grow, sesuai dengan perkembangan kebutuhan segmen enterprise. Fitur utama layanan VAS Advance WoCM dapat dikastemisasi sesuai dengan kebutuhan.

- Revenue share sebagai hasil kerjasama dengan key partner.

- Key Partnerships

- Kerjasama dengan penyedia teknologi WoCM.

- Kerjasama dengan penyedia big data.

- Kerjasama dengan advertiser atau agency, konsultan CRM, konsultan riset, dll.

- Key Activities

- Aktivitas terkait penyediaan dan pengelolaan infrastruktur, dashboard, advertising. 
- Aktivitas terkait pengelolaan

backroom, marketing, sales, help desk.

- Key Resources

- Aset meliputi infrastruktur, aplikasi, lisensi, dashboard.

- Backroom support

- SDM

- Cost Structure

- Biaya operasional pengelolaan perangkat dan aplikasi.

- Biaya lisensi

- Biaya marketing

b.Provider wifi perlu melakukan kerjasama dengan penyedia teknologi WoCM dalam menghasilkan layanan VAS Advance WoCM.

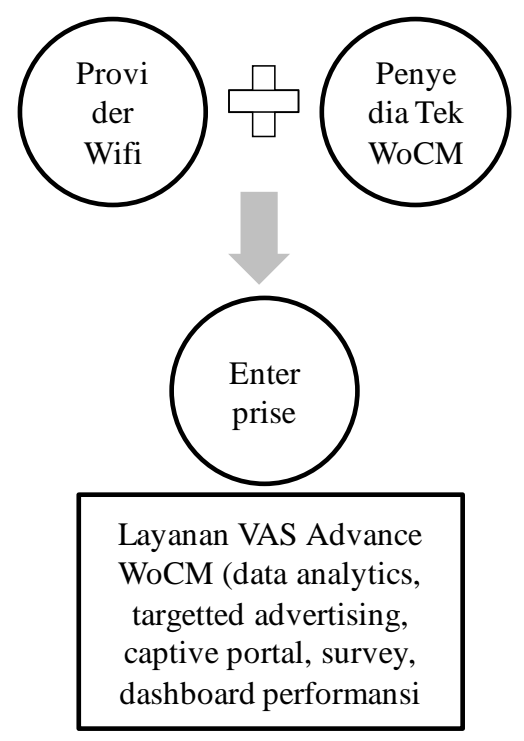

Gambar 12.

Layanan VAS Advance WoCM bagi Provider Wifi di Indonesia

Terdapat beberapa alternatif kerjasama yang dapat disesuaikan dengan kondisi network eksisting provider wifi:
- Alternatif 1 kerjasama: penyedia teknologi WoCM menyediakan keseluruhan network dan sistem (Gambar 13.). 


$\left.\begin{array}{|c|}\hline \text { Application } \\ \hline \text { Data } \\ \hline \text { Runtime } \\ \hline \text { Middleware } \\ \hline \text { O/S } \\ \hline \text { Virtualization } \\ \hline \text { Servers } \\ \hline \text { Storage } \\ \hline \text { Manage } \\ \text { oleh } \\ \text { Provider } \\ \text { Teknologi } \\ \text { WoCM } \\ \\ \end{array}\right]$

Gambar 13.

Alternatif 1 - Rekomendasi Kerjasama

- Alternatif 2 kerjasama: sebagian network dikelola oleh penyedia teknologi WoCM. Adapun application dan data dapat dikelola oleh provider wifi ataupun dikelola oleh penyedia big data. Untuk alternatif kedua ini, provider wifi perlu menjalin kerjasama dengan penyedia big data (Gambar 14.).

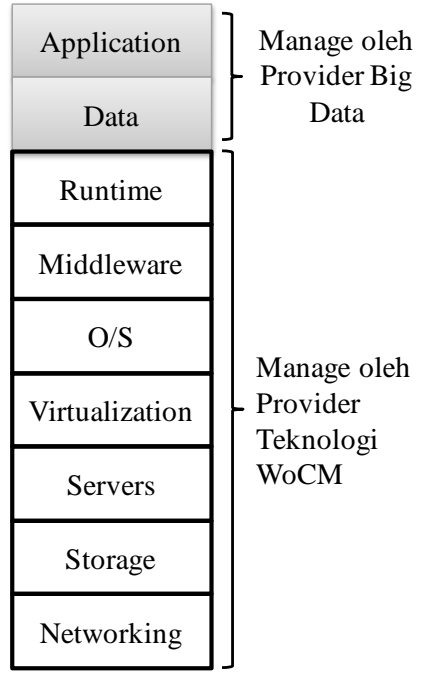

Gambar 14.

Alternatif 2 - Rekomendasi Kerjasama 
c. Provider wifi perlu melakukan kerjasama dengan pihak lain, seperti advertiser, agency, spesialis CRM, dll. Hal ini dimaksudkan untuk lebih menyempurnakan layanan VAS Advance
WoCM. Dengan demikian semakin terbuka peluang penambahan revenue provider wifi yang diperoleh sebagai dampak dari berbagai kerjasama yang dibangun (Gambar 15.).

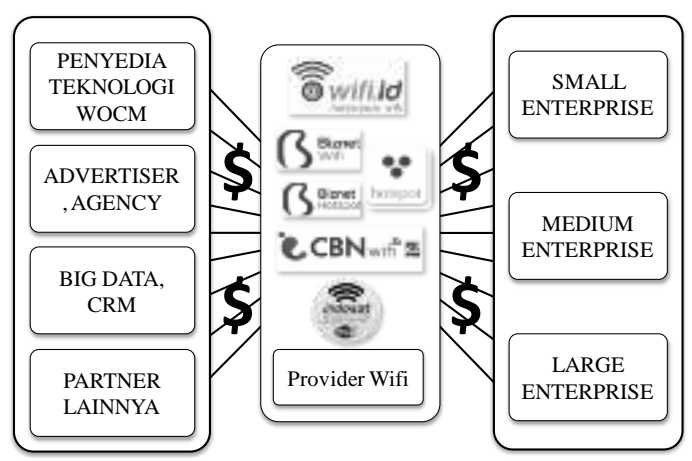

Gambar 15.

Kerjasama Provider Wifi dengan Pihak ke-3 Lainnya

d.Provider wifi perlu melakukan resegmentasi layanan wifi sehubungan adanya layanan baru VAS Advance WoCM. Hal ini akan disesuaikan dengan perkembangan kebutuhan segmen enterprise yang telah menjadi pelanggan, segmen enterprise yang baru memiliki status calon pelanggan, maupun segmen enterprise yang telah berlangganan connectivity ke provider wifi lainnya.
Terdapat 3 alternatif segmentasi seperti berikut ini.

- Segmen-1 : untuk pelanggan segmen enterprise eksisting yang telah berlangganan connectivity, akan ditawarkan layanan VAS Advance WoCM yang tentunya memiliki UVP (Unique Value Preposition) baru dimana segmen enterprise akan merasakan manfaat lain tidak sekedar hanya layanan connectivity bagi pelanggan. Dengan 
layanan baru VAS Advance WoCM

beserta kehandalan fitur-fiturnya, segmen enterprise akan lebih leluasa dalam mendesain dan mengelola program marketing termasuk program promosi, memperoleh insight bisnis lewat data analytics, dan mengontrol penuh performansi bisnis lewat dashboard. Tujuan segmen enterprise yaitu kepuasan pelanggan, loyalitas pelanggan, serta pencapaian target bisnis, akan dapat diwujudkan.

Disini provider wifi akan memperoleh tambahan revenue dari layanan VAS Advance WoCM, ataupun revenue dari paket bundling connectivity dan VAS Advance WoCM (Gambar 16.).

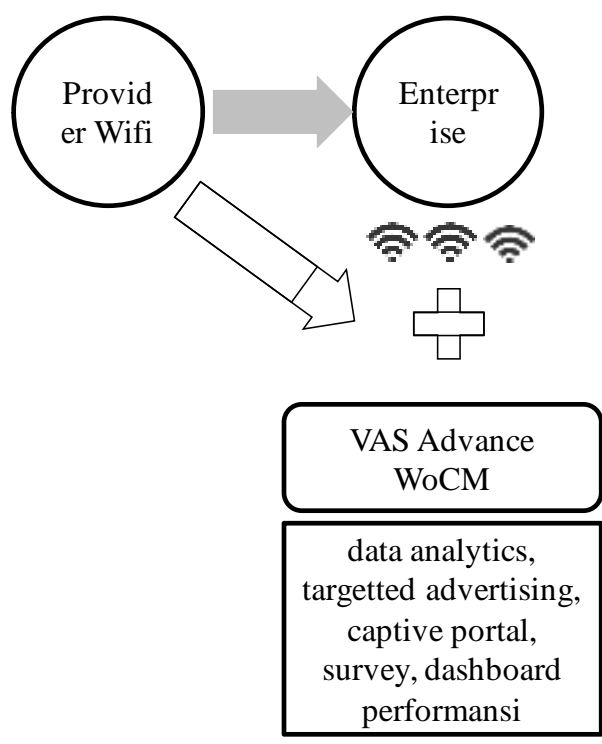

Gambar 16.

Segmen 1

- Segmen 2 : Untuk calon pelanggan segmen enterprise yang belum memiliki connectivity, dapat ditawarkan connectivity sekaligus VAS Advance
WoCM. Provider wifi akan memperoleh tambahan revenue dari layanan connectivity dan sekaligus VAS Advance WoCM. Provider wifi dapat melakukan 
berbagai skema bundling atas kedua layanan tersebut (Gambar 17.).

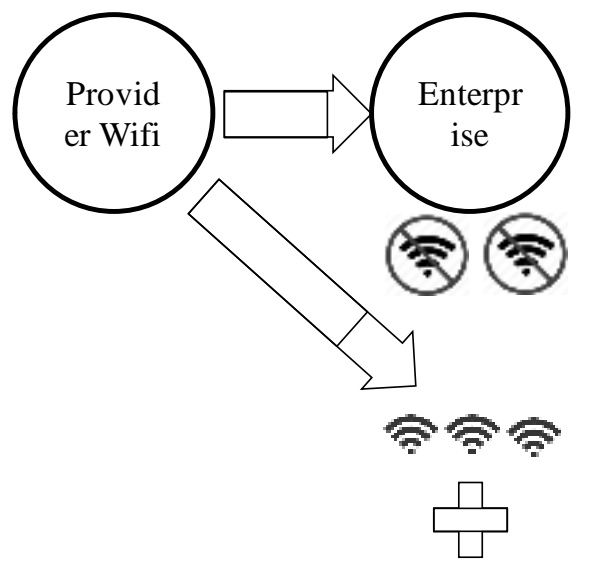

\section{VAS Advance} WoCM

data analytics, targetted advertising, captive portal, survey, dashboard performansi

Gambar 17.

Segmen 2

- Segmen 3 : Untuk calon pelanggan segmen enterprise yang telah berlangganan connectivity dari provider wifi lain atau pelanggan OLO (Other License Operator), juga bisa ditawarkan VAS Advance WoCM. Jadi dengan teknologi WoCM tidak membatasi suatu provider wifi dalam menawarkan layanan VAS Advance WoCM kepada segmen enterprise yang telah menjadi pelanggan connectivity provider wifi lainnya. Revenue akan berasal dari layanan VAS Advance WoCM (Gambar 18.). 


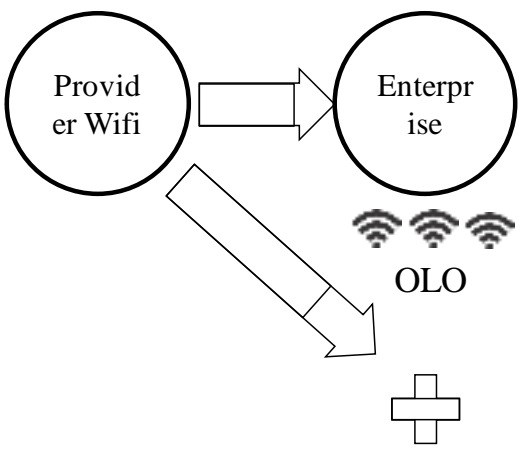

VAS Advance WoCM

data analytics, targetted advertising, captive portal, survey, dashboard performansi

Gambar 18 .

Segmen 3

e.Provider wifi perlu melakukan perbaikan terhadap materi komunikasi layanan wifi dengan tujuan untuk menyampaikan pesan adanya benefit baru layanan (VAS

Advance WoCM) terutama bagi segmen enterprise (Gambar 19.).

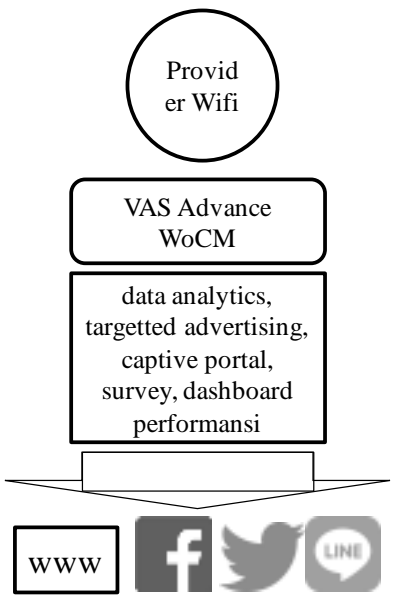

Gambar 19.

Komunikasi Layanan VAS Advance WoCM pada Setiap Channel 
Setiap channel yang dimiliki oleh provider wifi harus memuat materi komunikasi yang sama utamanya pada website dan social media yang dimiliki.

f. Provider wifi perlu mempertimbangkan waktu lamanya implementasi termasuk inisiasi kerjasama dengan penyedia teknologi WoCM, penyedia teknologi cloud, penyedia big data, serta pihak-pihak lainnya. Kecepatan implementasi menjadi hal yang utama, dikarenakan opportunity yang sama juga dihadapi oleh provider wifi lainnya. Provider wifi yang segera melaksanakan implementasi teknologi WoCM ini akan unggul dibanding provider wifi lainnya 


\section{DAFTAR PUSTAKA}

Microsoft, Cloud Computing: What is Infrastructure as a Service. 2011. Diakses dari https://technet.microsoft.com/en-us/magazine/hh509051.aspx

Microsoft, Best Practices for Updating Virtual Machines in Microsoft Azure IaaS Deployments. 2015. Diakses dari https://blogs.msdn.microsoft.com/azuresecurity/2015/12/08/best-practices-forupdating-virtual-machines-in-microsoft-azure-iaas-deployments/

Ostelwalder, A., \& Pigneur, Y. 2015. Business Model Generation (cetakan ke-8). Jakarta: PT. Elex Media Komputindo

Cloud4Wi Introduces Volare ${ }^{\mathrm{TM}}$, the First True Brand-Building Services Platform for Guest Wi-Fi. 2016. Diakses dari http://cloud4wi.com/cloud4wi-introduces-volare-the-first-true-brand-buildingservices-platform-for-guest-wi-fi/

Cloud4Wi Pricing, offering for every need. 2016. Diakses dari cloud4wi.com/pricing

Cloud4Wi Ecosystem Partners, Discover the industry leaders we work with. 2016. Diakses dari http://www.cloud4wi.com/ecosystem-partners/

Tanaza Technologi partners. 2016. Diakses dari https://www.tanaza.com/technology-partners/

IDC: \$2.5 Billion in Cloud-Managed Wi-Fi by 2018. 2014. Diakses dari http://www.telecompetitor.com/idc-2-5billion-in-cloud-managed-wi-fi-by-2018/

Social Networks+Wi-Fi = Social Wi-Fi. It sells itself!. 2016. Diakses dari https://www.tanaza.com/grow-wifi-sales/

Tanaza Wi-Fi Networking And Social Hotspots Made Easy.pdf. 2015. Diakses dari http://www.tanazamalaysia.com/wp-content/uploads/2016/04/Tanaza-Brochure.pdf

Tanaza Superpowers for Your Wi-Fi.pdf. 2014. Diakses dari http://www. tanaza.com/wpcontent/uploads/2014/07/SUPERPOWERS.pdf

Biznet. 2016. Diakses dari http://www.biznetwifi.com/id/

Biznet. 2016. Diakses dari http://www.biznethotspot.com/id/

Elevate your digital lifestyle with our new CBN Wifi. (2016). Diakses dari http://new.cbn.net.id/retailresidential/details/cbn-wifi

Melsa. 2016. Diakses dari http://melsa.net.id/main/ProductView/hotspot_premium

Indosat. 2016. Diakses dari https://indosatooredoo.com/id/personal/connectivity/super-wifi

BT Wifi Online analytics for the offline world. 2016. Diakses dari http://www.btwifi.co.uk/wifi-forbusiness/insight/

Singtel Generate business revenue with Enterpise WiFi. (2016). Diakses dari http://www1.singtel.com/business/products-and-services/managed-services/enterprise-wifi-as-aservice.html 